\title{
DE
} DE GRUYTER OPEN

\section{DETERMINATION OF THE METABOLIC RATE AND WORK ARDUOUSNESS CLASS FOR WORKERS IN COAL MINES - THE RESULTS OF IN SITU RESEARCH}

\author{
OKREŚLENIE TEMPA METABOLIZMU I KLAS CIĘŻKOŚCI PRACY PRACOWNIKÓW \\ KOPALŃ WĘGLA KAMIENNEGO - WYNIKI BADAŃ „IN-SITU”
}

\begin{abstract}
Considering different duties and activities among miners working in underground coal mines, their work is connected with variable metabolic rate. Determination of this rate for different workplace was the aim of the research and was the base for set up the work arduousness classes for the workplace (according to the standard PN-EN 27243). The research covered 6 coal mines, 268 workers and 1164 series of measurements. Metabolic rate was established on the base of heart rate obtained from individual pulsometers (according to the standard PN-EN ISO 8996). Measurements were supplemented by poll surveys about worker and thermal environment parameters. The results showed significant variability of average heart rate-(from $87 \mathrm{bmp}$ to $100 \mathrm{bpm}$ ) with variance coefficient $14 \%$. Mean values of metabolic rate were from $150 \mathrm{~W} / \mathrm{m}^{2}$ to $207 \mathrm{~W} / \mathrm{m}^{2}$. According to the results, the most common class of work arduousness was at moderate metabolic rate (class 2 - moderate work), however, more intense work was found in headings, especially at " blind end" workplace.
\end{abstract}

Keywords: metabolic rate, work arduousness, climatic conditions, thermal discomfort index, underground coal mine

Ze względu na zakres obowiązków osób zatrudnionych w podziemnych wyrobiskach kopalń praca na różnych stanowiskach związana jest z różnym tempem metabolizmu pracowników. Jest to ważny czynnik wpływający na cieplne warunki pracy. Jego znajomość jest niezbędna do oceny komfortu lub dyskomfortu cieplnego pracowników. Celem pracy było określenie wydatku energetycznego (przyrostu metabolizmu) oraz ciężkości pracy pracowników zatrudnionych w podziemnych kopalniach węgla kamiennego. W celu określenia ciężkości pracy przeprowadzono pomiary tętna górników zatrudnionych na różnych stanowiskach w 6 kopalniach węgla kamiennego. Tętno mierzono w sposób ciągły podczas dniówki roboczej u 268 pracowników wykonujących swoje codzienne obowiązki na 10 różnych sta-

* SILESIAN UNIVERSITY OF TECHNOLOGY, FACULTY OF MINING AND GEOLOGY, UL. AKADEMICKA 2, 44-100 GLIWICE, POLAND

** INSTITUTE OF OCCUPATIONAL MEDICINE AND ENVIRONMENTAL HEALTH, DEPARTMENT OF PHYSICAL HAZARD WORK PHYSIOLOGY AND ERGONOMICS, UL. KOŚCIELNA 13, 41-200 SOSNOWIEC, POLAND

$1 \quad$ CORRESPONDING AUTHOR: Jan.Drenda@polsl.pl 
nowiskach pracy. Łącznie przeprowadzono 1164 cykle pomiarowe. Na podstawie średnich wartości tętna zgodnie z normą PN-EN ISO 8996 określono wartości wydatku energetycznego pracowników. Posłużyły one do zaklasyfikowania pracy na poszczególnych stanowiskach do jednej z klas ciężkości zgodnie z klasyfikacją zawartą w normie PN-EN 27243. Przeprowadzone badania ankietowe pozwoliły uwzględnić wiek, wzrost, masę ciała badanych oraz podstawowe parametry mikroklimatu środowiska pracy. Przedstawione w pracy zakresy zmienności, wartości odchylenia standardowego pokazały, że występowały znaczące różnice w wartościach tętna pracowników. Obserwowane średnie wartości tętna pracowników na analizowanych stanowiskach mieściły się w przedziale od 87do 100 skurczów na minutę przy współczynnikach zmienności dochodzących do 14\%. Średnie wartości wydatku energetycznego pracowników znajdowały się w przedziale od 150 do $207 \mathrm{~W} / \mathrm{m}^{2}$. Z przeprowadzonych badań wynika, że najczęściej wykonywaną pracą na objętych badaniami stanowiskach była praca o umiarkowanej ciężkości. Praca w przodkach korytarzowych charakteryzowała się podwyższoną intensywnością, przede wszystkim na stanowisku - górnik w przodku.

Słowa kluczowe: tempo metabolizmu, ciężkość pracy, warunki klimatyczne, wskaźnik dyskomfortu cieplnego, podziemna kopalnia węgla kamiennego

\section{Introduction}

During its lifetime, human body produces heat which is called metabolic heat. It allows to keep constant internal body temperature at $37^{\circ} \mathrm{C}$. Considering that only small amount of heat is necessary to maintain life processes and to do work activities, it can be stated that an organism is a perfect flow machine (an engine), especially under favorable microclimate conditions. Under that conditions the amount of heat which is produced during metabolism equals the amount of heat which is loss to the ambience. The amount of heat which is produced and transferred out during the unit of time is called metabolic energy production. Metabolic energy production is often assigned as heat stream flowing out from $1 \mathrm{~m}^{2}$ of human body. This is the right definition of metabolic rate (further assigned as $\mathrm{M}$ ) which is given in $\mathrm{W} / \mathrm{m}^{2}$.

Under adverse thermal environment conditions (warm and hot thermal environment) decrease or even lack of metabolic heat loss from a body can be noticed, therefore it leads to increase of a body internal temperature. This is the reason of heat stress, heat stroke, fainting or exhaustion.

Thermal safety of a worker is related to microclimate factors and worker factors. Microclimate factors are connected with temperature, humidity, air velocity and mean radiant temperature. The factors which are connected with a worker can be listed as: kind of a work, work arduousness, clothing (thermal resistance of clothes) and rate of acclimatization. Work class is the most important factor and it is partly referred to both intensity and kind of performed work. Complete assessment of thermal discomfort should include the influence of metabolism. In the world, there are dozens indices giving the description of heat hazard and they include metabolic energy production, e.g. heat stress index HSI, wet bulb global temperature WBGT; thermal work limit TWL; air cooling power ACP, M scale ACPM (Belding \& Hatch, 1955; Yaglou \& Minard, 1957; Wacławik, 2010; Brake \& Bates, 2002).

Silesian University of Technology also created an index which includes all mentioned above factors. It is called thermal discomfort index d (Drenda, 1993).

Recognition and analysis of microclimate parameters at workplaces and assessment of work class for the workers are crucial elements of estimation of climate conditions for work and its safety in the mines. 
The research activities have been carried out in the frameworks of the task no. 5 titled ,The recruiting requirements for miners working in hot underground mine environments" which was the part of a Polish strategic project: "The improvement of work safety in mines" being financed by The National Centre of Research and Development. It was coordinated and conducted by The Institute of Mining Technologies at Silesian University of Technology. The other members of the consortium were: AGH - University of Science and Technology - Faculty of Mining and Geo-engineering, EMAG - Institute of Innovative Technologies, Institute of Occupational Medicine and Environmental Health and CEN-MED - Professional Medical Research Center. The consortium also included the Polish Mining Companies - JSW S.A., KW S.A and KHW S.A.

The main aim of the task was to establish clear rules for thermal hazard identification and categorization. As the result, the rules should be given to proper employers and people in charge who are responsible for miners safety.

One subtask was focused on determination of the metabolic energy production of the miners and then their work class.

The characteristics of performed work at different workplaces was varied, therefore research was carried out in following groups of locations: longwalls, preparation headings, and in the excavations connected with the transport processes. Such an approach allowed to determine work class for the miners with particular range of duties at different workplaces. It is possible only during insitu research because research undertaken in climate chambers does not include the characteristics of a real workplace.

The regulations (e.g. PN-EN ISO 8996) give the values for metabolic energy production at different workplaces, however, they do not include the most important workplaces in underground mines where hot microclimate is excepted very often. There are several methods to determine metabolic energy production, but they have different level of accuracy. (Spioch, 1993; Domagała et al., 2013; PN-EN ISO 8996):

- classification based on the type of activity or a occupation,

- application of special tables including metabolic energy production values for different activities and timing,

- measurements of physiological parameters of the workers, e.g. heart rate, oxygen consumption, pulmonary ventilation).

The measurements of pulse among the workers (with application of pulsometers set up at their chests) were selected and they allowed to perform continuous research without disturbing real work.

\section{The methodology}

The research covered 6 coal mines and 268 miners employees in:

- a longwall: as a cutter-loader man, a supervision, a mechanic, an electrician, a helper;

- a heading: as a cutter-loader man, a miner in the blind end, a supervision, a mechanic, an electrician;

- transport divisions and conveyor transfer stations.

The research covered collecting the opinion polls and measurements of heart rate among the miners. The pulsometer Suunto Memory Belt was used for heart rate measurements. It was mounted at a chest of a miner allowing constant measurements without disturbing of performed 
work. Preliminary tests of the pulsometers have been carried out in one of selected mines. It allowed to check the device in situ.

Heart rate was measured starting from mounting the pulsometer at a chest just before descent to a mine up to the end of a shift (return to the surface). The devise had "data save" mode turned on and then all the data from internal memory was copied to HDD of a PC.

Supplementary information was collected by the questionnaires. It included: physical parameters of the air (dry bulb temperature, wet bulb temperature, air velocity), range and time of the work. Further analysis included also time of setting up the pulsometer, time of descent, time of walk to a workplace, time of ending the work, time of the return at the surface from a workstand and time of taking the pulsometer off.

The example of the analysis of Suunto printout is presented in Figure 1.

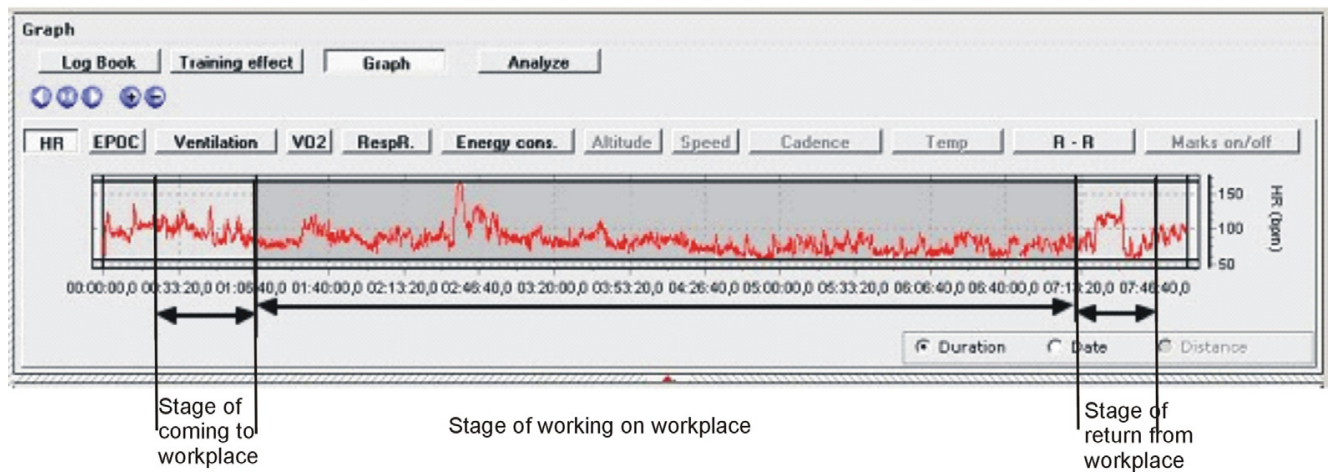

Fig. 1. The stages of the work from descent to return - Suunto printout (Final report, 2015)

Collected data was verified by:

- verification of pulsometer records including data from the algorithm of Training Manager software,

- verification of obtained data due to further analysis (quality of the record, additional information about performed work).

The research covered 268 miners and 1164 full shifts for them during 2-5 working days in a week. Verification established 711 measuring cycles ( $61 \%$ of total amount) for further analysis among 221 miners ( $82 \%$ of total number). The results covered:

- among workers in longwall - 27 cutter-loader men, 31 section men, 23 supervisors, 12 mechanics, electricians, 17 helpers;

- among workers in headings - 25 cutter-loader men, 16 miners in a blind end, 12 supervisors, 24 mechanics, electricians;

- 34 workers in transport divisions and at conveyor transfer stations.

Detailed data is collected in Table 1. The characteristics of group of the miners which was selected for the analysis including workplaces is presented in Table 2. 
Total number of miners $n$ and measurements $n^{\prime}$ in coal mines which were covered by the studies (Final report, 2015)

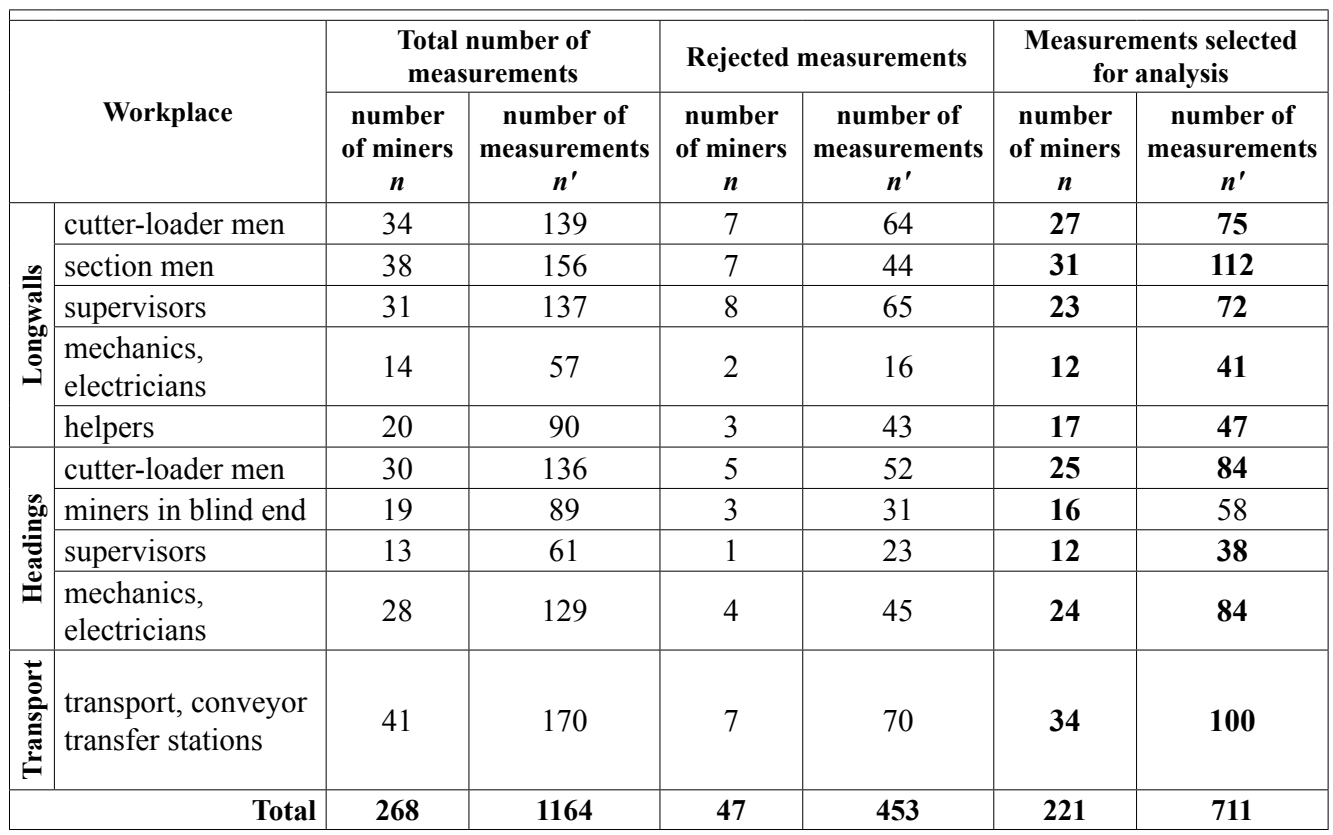

TABLE 2

Physiological characteristics of the workers (Final report, 2015)

\begin{tabular}{|c|c|c|c|c|c|c|}
\hline \multicolumn{2}{|r|}{$\begin{array}{c}\text { Workplace } \\
\text { (number of workers) }\end{array}$} & Value & Age & $\begin{array}{c}\text { Height } \\
\text { cm }\end{array}$ & $\begin{array}{l}\text { Body weight } \\
\text { kg }\end{array}$ & $\begin{array}{l}\text { Body Mass } \\
\text { Index }\end{array}$ \\
\hline \multirow{5}{*}{ 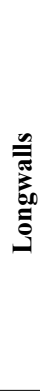 } & $\begin{array}{l}\text { cutter-loader men } \\
\quad(n=27)\end{array}$ & $\begin{array}{c}\text { mean value } \pm \mathrm{SD} \\
\text { variability }\end{array}$ & $\begin{array}{c}40 \pm 5 \\
21\end{array}$ & $\begin{array}{c}177 \pm 7 \\
25\end{array}$ & $\begin{array}{c}89 \pm 9 \\
35\end{array}$ & $\begin{array}{c}28,4 \pm 2,8 \\
12\end{array}$ \\
\hline & $\begin{array}{l}\text { section men } \\
(n=31)\end{array}$ & $\begin{array}{c}\text { mean value } \pm S D \\
\text { variability }\end{array}$ & $\begin{array}{c}38 \pm 5 \\
21\end{array}$ & $\begin{array}{c}177 \pm 6 \\
22\end{array}$ & $\begin{array}{c}85 \pm 12 \\
45\end{array}$ & $\begin{array}{c}26,9 \pm 3,1 \\
11,6\end{array}$ \\
\hline & $\begin{array}{l}\text { supervisors } \\
(n=23)\end{array}$ & $\begin{array}{c}\text { mean value } \pm \mathrm{SD} \\
\text { variability }\end{array}$ & $\begin{array}{c}34 \pm 7 \\
23\end{array}$ & $\begin{array}{c}179 \pm 6 \\
22 \\
\end{array}$ & $\begin{array}{c}85 \pm 11 \\
46\end{array}$ & $\begin{array}{c}26,6 \pm 3,1 \\
15,6 \\
\end{array}$ \\
\hline & $\begin{array}{c}\text { mechanics, electricians } \\
(n=12)\end{array}$ & $\begin{array}{c}\text { mean value } \pm S D \\
\text { variability }\end{array}$ & $\begin{array}{c}34 \pm 7 \\
22\end{array}$ & $\begin{array}{c}177 \pm 7 \\
18\end{array}$ & $\begin{array}{c}82 \pm 12 \\
37\end{array}$ & $\begin{array}{c}26,3 \pm 2,7 \\
8,2\end{array}$ \\
\hline & helpers $(n=17)$ & $\begin{array}{c}\text { mean value } \pm \mathrm{SD} \\
\text { variability }\end{array}$ & $\begin{array}{c}33 \pm 8 \\
25\end{array}$ & $\begin{array}{c}177 \pm 8 \\
24\end{array}$ & $\begin{array}{c}84 \pm 9 \\
33\end{array}$ & $\begin{array}{c}26,6 \pm 2,9 \\
9,2 \\
\end{array}$ \\
\hline \multirow{4}{*}{ 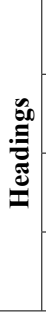 } & $\begin{array}{l}\text { cutter-loader men } \\
(n=25)\end{array}$ & $\begin{array}{c}\text { mean value } \pm S D \\
\text { variability }\end{array}$ & $\begin{array}{c}39 \pm 6 \\
20\end{array}$ & $\begin{array}{c}176 \pm 5 \\
16\end{array}$ & $\begin{array}{c}83 \pm 8 \\
32\end{array}$ & $\begin{array}{c}26,8 \pm 2,8 \\
11,3 \\
\end{array}$ \\
\hline & $\begin{array}{l}\text { miners in blind end } \\
\quad(n=16)\end{array}$ & $\begin{array}{c}\text { mean value } \pm \mathrm{SD} \\
\text { variability }\end{array}$ & $\begin{array}{c}37 \pm 7 \\
26\end{array}$ & $\begin{array}{c}176 \pm 7 \\
25\end{array}$ & $\begin{array}{c}86 \pm 11 \\
40\end{array}$ & $\begin{array}{c}27,8 \pm 1,9 \\
6,8 \\
\end{array}$ \\
\hline & $\begin{array}{l}\text { supervisors } \\
(n=12)\end{array}$ & $\begin{array}{c}\text { mean value } \pm \mathrm{SD} \\
\text { variability }\end{array}$ & $\begin{array}{c}32 \pm 6 \\
19\end{array}$ & $\begin{array}{c}181 \pm 7 \\
25\end{array}$ & $\begin{array}{c}85 \pm 10 \\
41\end{array}$ & $\begin{array}{c}26,1 \pm 3,4 \\
10,5 \\
\end{array}$ \\
\hline & $\begin{array}{c}\text { mechanics, electricians } \\
(n=24)\end{array}$ & $\begin{array}{c}\text { mean value } \pm \mathrm{SD} \\
\text { variability }\end{array}$ & $\begin{array}{c}37 \pm 6 \\
19\end{array}$ & $\begin{array}{c}178 \pm 7 \\
29 \\
\end{array}$ & $\begin{array}{c}85 \pm 15 \\
60 \\
\end{array}$ & $\begin{array}{c}26,7 \pm 4,1 \\
19,0 \\
\end{array}$ \\
\hline
\end{tabular}


TABLE 2. Continued

\begin{tabular}{|c|c|c|c|c|c|c|}
\hline & transport, conveyor & mean value \pm SD & $36 \pm 8$ & $175 \pm 6$ & $80 \pm 12$ & $26,0 \pm 3,5$ \\
\hline & transfer stations & variability & 36 & 23 & 60 & 18,7 \\
\hline
\end{tabular}

$\mathrm{SD}-$ standard deviation

\subsection{Determination of physical air parameters}

Carrying out the research required collecting the physical parameters of the air:

- dry and wet bulb temperatures measured by Assmann's psychrometer,

- air velocity measured by vane anemometer.

The results allowed to determine relative humidity at selected workplaces.

The studies were carried out in excavations having variable thermal conditions. In longwalls dry bulb temperature varied from $24^{\circ} \mathrm{C}$ to $32,2^{\circ} \mathrm{C}$, relative humidity varied from $68 \%$ to $96 \%$ and air velocity changed from $0,5 \mathrm{~m} / \mathrm{s}$ to $4,1 \mathrm{~m} / \mathrm{s}$. In headings dry bulb temperature varied from $23,1^{\circ} \mathrm{C}$ to $31,5^{\circ} \mathrm{C}$, relative humidity varied from $71 \%$ to $96 \%$ and air velocity changed from $0,3 \mathrm{~m} / \mathrm{s}$ to $1,7 \mathrm{~m} / \mathrm{s}$. Detailed results are collected in Table 3 .

The range of air parameters (Final report, 2015)

\begin{tabular}{|c|c|c|c|c|}
\hline \multirow{2}{*}{\multicolumn{2}{|c|}{ Workplace }} & \multicolumn{3}{|c|}{ Range } \\
\hline & & Temperature & Relative humidity & Air velocity \\
\hline \multirow{5}{*}{ 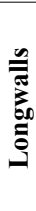 } & cutter-loader men & $24,0-31,5$ & $73-92$ & $0,8-4,1$ \\
\hline & section men & $24,0-31,8$ & $74-92$ & $0,8-4,1$ \\
\hline & supervisors & $24,0-31,5$ & $70-95$ & $0,8-4,1$ \\
\hline & mechanics, electricians & $24,0-31,0$ & $80-96$ & $0,5-3,5$ \\
\hline & helpers & $24,4-32,2$ & $68-92$ & $0,8-4,1$ \\
\hline \multirow{4}{*}{ 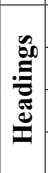 } & cutter-loader men & $23,2-31,4$ & $71-96$ & $0,3-1,1$ \\
\hline & miners in blind end & $23,2-31,4$ & $71-87$ & $0,4-1,7$ \\
\hline & supervisors & $23,6-31,5$ & $71-88$ & $0,3-1,2$ \\
\hline & mechanics, electricians & $23,1-31,5$ & $71-88$ & $0,4-1,5$ \\
\hline 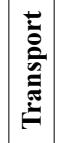 & $\begin{array}{l}\text { transport, conveyor transfer } \\
\text { stations }\end{array}$ & $20,0-30,7$ & $60-90$ & $0,3-6,2$ \\
\hline
\end{tabular}

\subsection{Metabolic rate and class of the work}

Determination of metabolic rate was based on average values of obtained heart rates. Then metabolic rate was computed using formulas included in standard PN-EN ISO 8996 : Ergonomics of the thermal environment - Determination of metabolic rate - annex $\mathrm{C}$. They are based on relation between metabolic rate (given in $\mathrm{W} / \mathrm{m}^{2}$ ) and heart rate, body weight, age, sex etc. 
Obtained results allowed to determine class of the work (among 5 classes) for different workplaces. Table 4 gives classes as: 0 - resting, 1 - low metabolic rate (light work), 2 - moderate metabolic rate (moderate work), 3 - high metabolic rate (hard work), 4 - very high metabolic rate (very hard work).

TABLE 4

Work classes according to PN-EN 27243

\begin{tabular}{|c|c|c|}
\hline \hline Class & Metabolic rate, $\boldsymbol{M}, \mathbf{W} / \mathbf{m}^{\mathbf{2}}$ & Mean metabolic rate, $\boldsymbol{M}_{\boldsymbol{s} r}, \mathbf{W} / \mathbf{m}^{\mathbf{2}}$ \\
\hline 0 & $M<65$ & 65 \\
\hline 1 & $65<M<130$ & 100 \\
\hline 2 & $130<M<200$ & 165 \\
\hline 3 & $200<M<260$ & 230 \\
\hline 4 & $M>260$ & 290 \\
\hline
\end{tabular}

\section{The results}

\subsection{Time of work stages}

Time of work stages (descent - return) depends on many factors: net of excavations, location of driven headings and preparation excavations, longwalls and their location due to intake shaft, schedule of duties at different work-stands, climatic conditions etc.

The questionnaires gave information about mentioned-above aspects.

The longest average time of being underground (descent - return) was noticed for the workers in longwall. It was above 7 hours among cutter-loader men and section men with working at workplace averagely by 5,5 hours. The results also indicate significant difference in times of different work stages due to both workplaces and or the same workplaces but different mines. The largest variability was connected with time of passing between shaft bottom and a workplace and between workplace and shaft top.

Average time of work stages for different work-stands are given in Figure 2.

\subsection{Heart rate}

Heart rate diagrams with average values for selected stages and with values for total time of the work were estimated (Fig. 1). For each miner the data from the diagram was saved and analyzed. Table 5 shows average values of miners heart rate achieved during the research.

Figure 3 shows average heart rates of the miners during their work at workplaces and during all evaluated time (descent - return) totally for 6 mines. Obtained results indicate small differences in heart rate between work stage and total time. Walk to the workplace and further return are also connected with significant metabolic rate.

However, there are crucial differences between particular workplaces. The highest values of heart rate were noticed at "miners in heading" stand (100/min - from descent to return), 101/ min - during the work at workplace). The lowest heart rate was observed at "helper" (90/min) and "supervisor" (87/min) in a longwall (Fig. 4). Similar rules were observed due to pulse differences (different values at different workplaces what was related to variable microclimate conditions). 


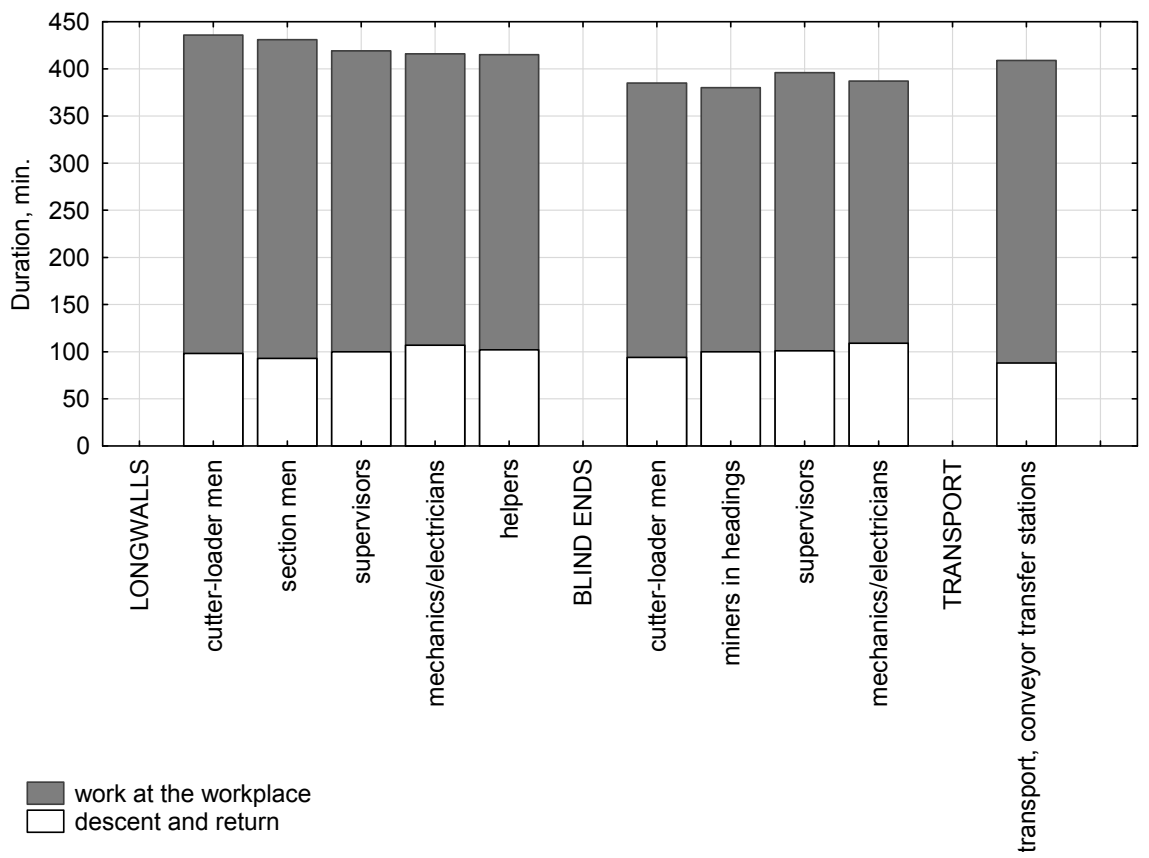

Fig. 2. Average time (minutes) of work stages between descent and return (own source)

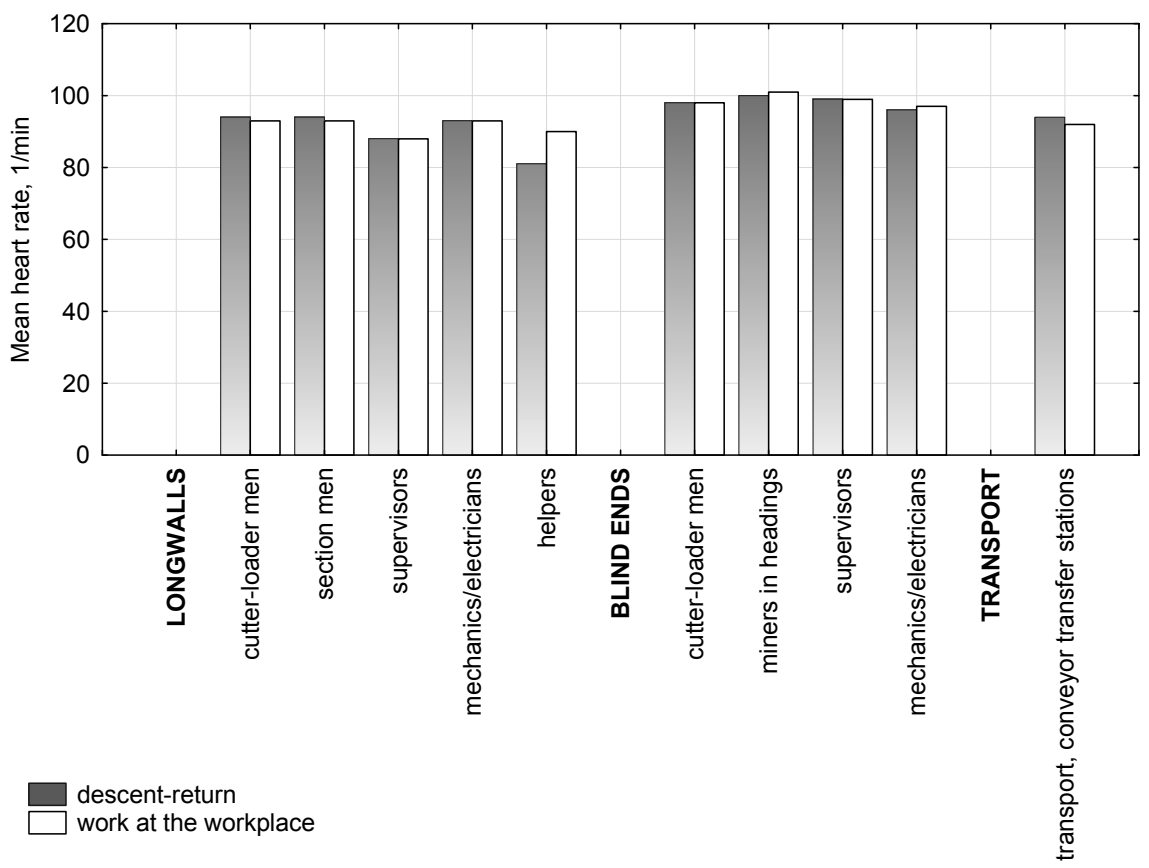

Fig. 3. Average values of pulse among the workers at workplace (own source) 
Average values of heart rate among the miners during descent-return stage

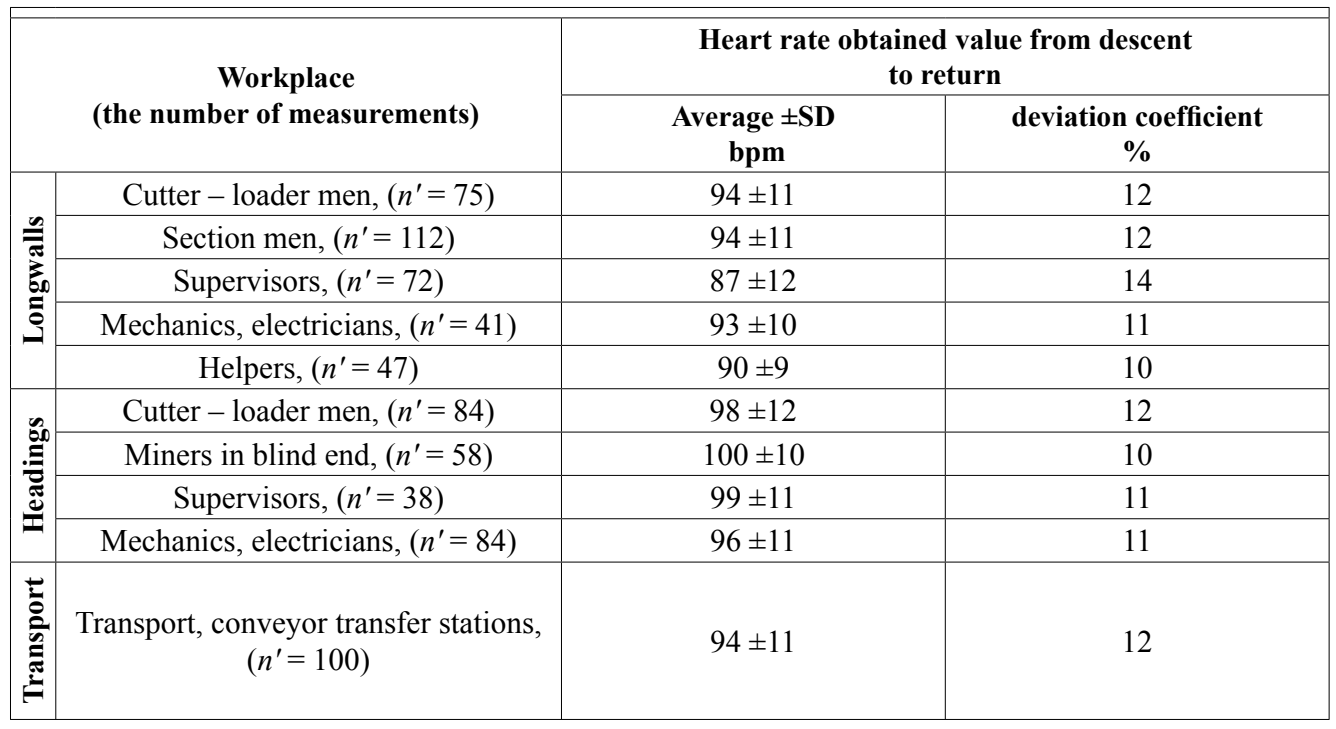

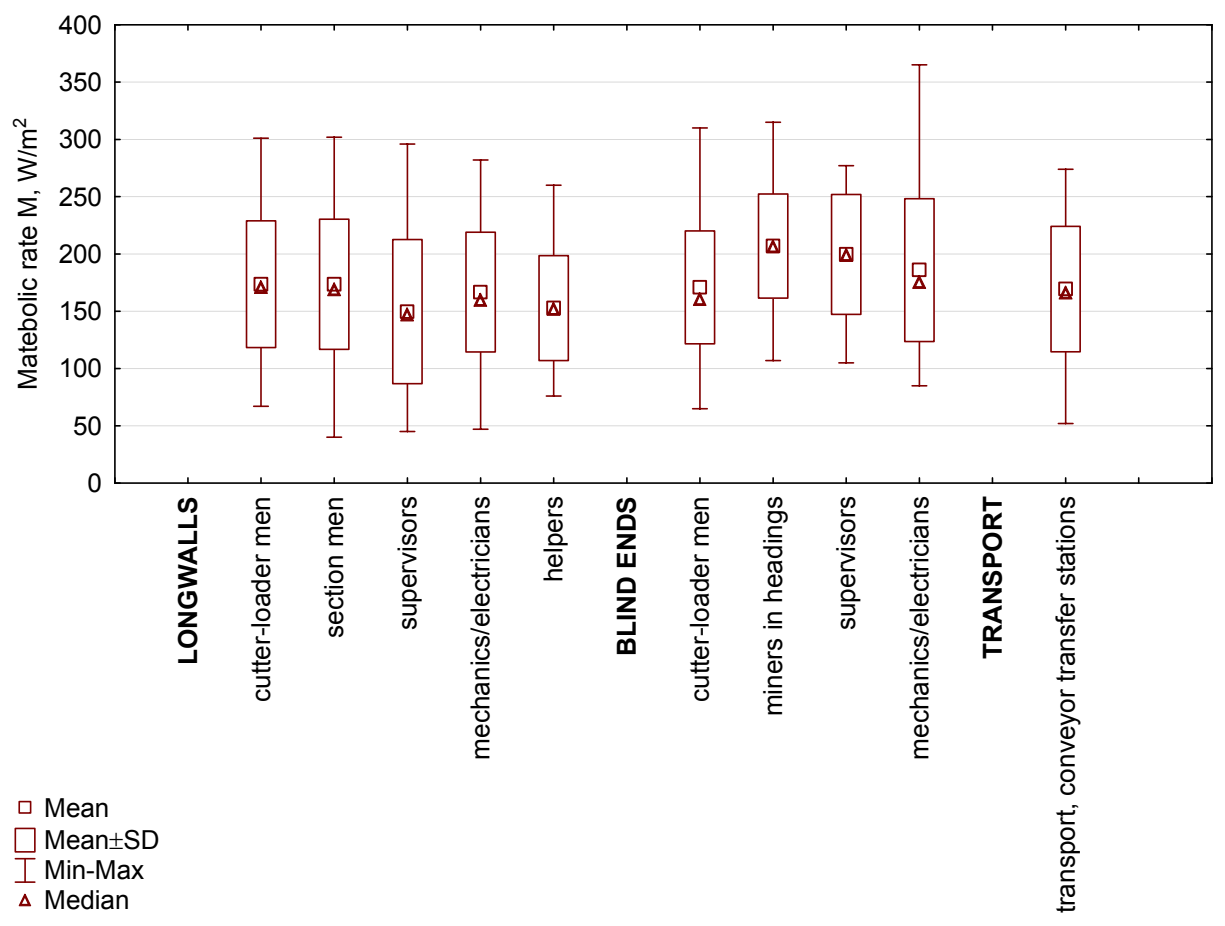

Fig. 4. Statistical elaboration of heart rate results for the miners at different workplaces (own source) 


\subsection{Metabolic rate and work class}

Average metabolic rate was assessed basing on obtained results of heart rate and physiological parameters (age, mass). Figure 5 shows statistical elaboration of the results due to metabolic rate. It is clear to see significant variability of the values for the workers at the same workplace and differences between the workplaces. Average metabolic rate obtained during the route to and from the workplace was similar as obtained at descent-return period. It is the proof that metabolic rate which is related to walk to/from workplace can not be ignored. Therefore, values of metabolic rate presented in Fig. 5 are referred to total time starting from descent and ending at return.

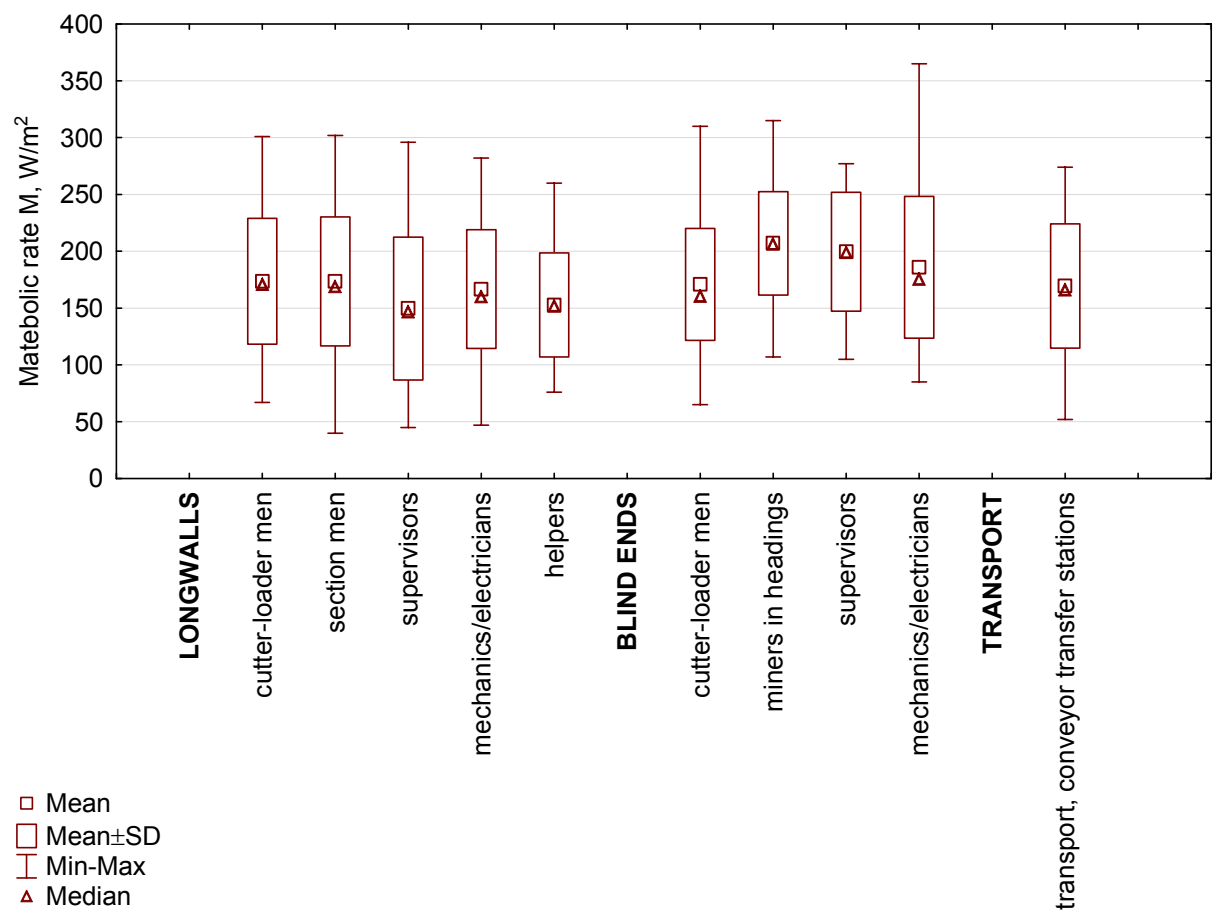

Fig. 5. The results of metabolic rate among miners at different workplaces (own source)

Obtained metabolic rates were the base for their classification (the levels) according to Table 4 for the workers at different workplaces.

Table 6 shows computed average values of metabolic rate and sufficient work classes. The values are from 150 to $207 \mathrm{~W} / \mathrm{m}^{2}$. The lowest average value is related to supervisors in exploitation divisions, therefore their work class was set as 2 (moderate). Supervisors in preparatory divisions were loaded by metabolic rate as $200 \mathrm{~W} / \mathrm{m}^{2}$. The most hard work was done by the miners in the blind ends. Considering obtained average value of metabolic rate it can be stated that none of workplaces is forcing to do light or very hard work. However, single maximal or minimal values can be fit to those classes. 
Metabolic rate and work class for miners at different workplaces in underground coal mines

\begin{tabular}{|c|c|c|c|c|}
\hline \multicolumn{2}{|r|}{ Workplace } & \multirow{2}{*}{$\begin{array}{c}\begin{array}{c}\text { Average metabolic rate } \\
\mathbf{W} / \mathbf{m}^{\mathbf{2}}\end{array} \\
174 \\
\end{array}$} & \multirow{2}{*}{$\begin{array}{c}\text { Confidence interval } \\
161-186\end{array}$} & \multirow{2}{*}{$\begin{array}{c}\text { Work class } \\
2\end{array}$} \\
\hline \multirow{5}{*}{ 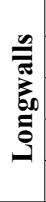 } & cutter-loader men & & & \\
\hline & section men & 174 & $163-184$ & 2 \\
\hline & supervisors & 150 & $135-164$ & 2 \\
\hline & mechanics, electricians & 167 & $150-183$ & 2 \\
\hline & helpers & 153 & $139-166$ & 2 \\
\hline \multirow{4}{*}{ : } & cutter-loader men & 171 & $160-182$ & 2 \\
\hline & miners in blind end & 207 & $195-219$ & $2 / 3$ \\
\hline & supervisors & 200 & $182-217$ & $2 / 3$ \\
\hline & mechanics, electricians & 186 & $172-199$ & 2 \\
\hline 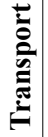 & $\begin{array}{l}\text { transport, conveyor } \\
\text { transfer stations }\end{array}$ & 169 & $159-180$ & 2 \\
\hline
\end{tabular}

\section{Conclusions}

The results which are presented in the article are some generalization for particular group of the workers at specified workplaces. Given: range of variability, standard deviation of measured heart rate (Fig. 4) and computed metabolic rate (Fig. 5) show that significant differences in the results are possible and they ground in individual predispositions and conditions of a worker.

Similar results of mean value and median value for pulse and metabolic rate for particular workplaces (Fig. 5) indicate that there are no results significantly varying from them.

According to the results, the most common work was at moderate intensity (Fig. 6).

Work done in headings is connected with more intensity, especially for "miner in blind end" workplaces. Metabolic rate exceeded $200 \mathrm{~W} / \mathrm{m}^{2}$ in that case, what is related to intense work.

Estimated mean values of metabolic rate can be the base for thermal comfort assessment in hot and dangerous work conditions.

They can be also applied for determination of rules of employment process in difficult climatic conditions, considering safety features. Thermal discomfort index can be useful because metabolic rate is one of crucial input data with its application.

This research has been carried out in the framework of "The recruiting requirements for miners working in hot underground mine environments", part of a Polish strategic project:

"The improvement of work safety in mines" SP/K/5/143275/11

\section{References}

Belding H.S., Hatch T.F., 1955. Index for evaluating heat stress in terms of resulting physiological strain. Heat Pip Air Condit. 27, 129-136. 
Brake D.J., Bates G.P., 2002. Limiting Metabolic Rate (Thermal Work Limit) as an Index of Thermal Stress. Applied Occupational and Environmental Hygiene, 17 (3), 176-186.

Domagała L., Kułagowska E., Karolak I., 2013. Określenie rodzajów i ciężkości pracy górników w kopalniach węgla kamiennego. Materiały konferencyjne - Konferencja naukowo-techniczna „Opracowanie zasad zatrudniania pracowników w warunkach zagrożenia klimatycznego w podziemnych zakładach górniczych”, Gliwice - Rybnik 27.06.2013 r., 43-54.

Drenda J., 1993. Dyskomfort cieplny w środowiskach pracy kopalń głębokich. Zeszyty Naukowe Politechniki Śląskiej, z. 213, Gliwice.

Final report 2015. Poprawa bezpieczeństwa pracy w kopalniach (The improvement of work safety in mines), part no. 5 „Opracowanie zasad zatrudniania pracowników w warunkach zagrożenia klimatycznego w podziemnych zakładach górniczych”, Strategic project no. SP/K/5/143275/11.

PN-EN ISO 8996:2005. Ergonomia środowiska termicznego - Okréslenie tempa metabolizmu.

PN-EN 27243:2005. Środowiska gorace. Wyznaczanie obciążenia termicznego działajacego na człowieka podczas pracy, oparte na wskaźniku WBGT.

Spioch F.M., 1993. Oznaczanie wydatku energetycznego i ocena ciężkości pracy. Instytut Medycyny Pracy i Zdrowia Środowiskowego, Sosnowiec.

Wacławik J., 2010. Wentylacja kopalń. Tom 2, Wydawnictwo AGH, Kraków.

Yaglou C.P., Minard D., 1957. Control of heat causualties at military training centers. Am. Med. Ass. Arch. Ind. Hlth. 16, 302-316. 